\title{
Motivation as preparatory department students' personal readiness to learn Russian as a foreign language
}

\section{La motivación como la preparación personal de los estudiantes de las facultades preparatorias para estudiar el ruso como idioma extranjero}

\author{
Kozlovskaya Ekaterina* \\ Peoples' Friendship University of Russia (RUDN University), Moscow, Russian \\ Federation \\ ORCID ID: https://orcid.org/0000-0002-6308-725X
}

Gorbulinskaya Elena

Kabardino-Balkar state University named after Kh. M. Berbekov, Nalchik, Russian FederationORCID ID: https://orcid.org/0000-0002-8543-7935

Kosareva Tatiana

Moscow State Linguistic University, Moscow, Russian Federation ORCID ID: https://orcid.org/0000-0002-8174-9106

Received 10-10-20 Revised 11-12-20 Accepted 01-13-21 On line 01-14-21

*Correspondence

Email: olfiss@list.ru
Cite as:

Kozlovskaya, E., Gorbulinskaya, E., \& Kosareva, T. (2020) Motivation as preparatory department students' personal readiness to learn Russian as a foreign language. Propósitos y Representaciones, 9 (SPE1), e860. Doi: http://dx.doi.org/10.20511/pyr2021.v9nSPE1.860 


\section{Summary}

The article covers motivation as a complex psychopedagogical process reflecting the level of preparatory department students' personal readiness to learn Russian as a foreign language. The article shows that teaching Russian is a complex multi-dimensional process closely linked to an individual's motivational abilities. The author analyzes educational and cognitive motivation along with motivation for foreign-language communication. The article describes the results of research on preparatory department students' personal motivation.

Keywords: motivation, learning Russian as a foreign language, preparatory department.

\section{Resumen}

El artículo considera la motivación como un proceso psicologo-pedagógico complejo que refleja el nivel de preparación personal de los estudiantes de las facultades preparatorias para estudiar el ruso como idioma extranjero. El artículo muestra que el aprendizaje del idioma ruso es un proceso complejo de varios niveles, estrechamente relacionado con las habilidades motivacionales del individuo. El artículo analiza la motivación educativa y cognitiva y la motivación de la actividad del habla extranjera, describe los resultados del estudio de la motivación personal para los estudiantes de la facultad preparatoria.

Palabras clave: Palabras de clave: motivación, estudio del ruso como idioma extranjera, facultad preparatoria.

\section{Introduction}

Broadening international contacts increase standards for vocational training of future specialists (N.G. Ershova 2012; L.E. Solyankina 2013; S.V. Khrebina \& M.V. Khrebin 2014). The level of professionalism is closely linked to the level of professional and educational motivation. The acknowledgement of motivation as the key to self-determination and personal growth determines its interdisciplinary nature. Motivation, integrated in psychopedagogical research, can be studied from the point of the factor enhancing foreign students' interest to study at Russian universities even in the pre-university period.

Medical and biological preparatory department students' motivation is a matter of psychologists' special attention. The study at medical departments requires maximum energy and efforts. Foreign students' successful study in the pre-university period determines their progress at medical departments and in their further professional activity. "With low motivation among medical students, it is hard to improve the quality and culture of medical care, as well as enhance effectiveness of medical organizations and health care system in general" (Povarenkov \& Slepko \& Tsymbalyuk 2014).

\section{Background}

The research on educational motivation is a promising area of psychopedagogical studies. Psychologists have proved that studying the formation of professional consciousness in educational process is one of the most relevant problems in psychological researches. L.I. Bozhovich, S.V. Efimenko, A.K. Markova, T.A. Matis, Yu.M. Orlov and many other scholars contributed greatly to the issues related to educational motivation.

The personal activity approach, which is developed by B.V. Belyaev, I.A. Zimnyaya, V.D. Shadrikov and other researchers in the context of learner-oriented approach to education, has also had a great impact on the formation of motivation theory. The new aspect of studying this theory is related to overestimated values of professionalization. Higher demands for 
professional growth and education level increased students' responsibility for their future professional activity.

L.M. Bazavlutskaya (2016), I.A. Batkaeva, E.A. Mitrofanova (2012), D.S. Dolya, D.V. Tikhonov (2016) and other scholars carried out numerous researches on personal components of medical students' motivation.

The problems of learner-oriented choice of future profession, vocational training and professional motivation were studied by N.P. Nosenko (2006), A.A. Passishnikov (2009), A.A. Rean (2013), E.A. Klimov, 2013; Yu.P. Povarenkov, 2014; E.P. Ilyin, 2012, and others.

The concept of modern educational paradigm mainstreams psychological studies on motivational factors. Nowadays, psychologists agree on the importance of motivation in productive activity (S.A. Druzhilov 2012-2013; E.A. Klimov 2003, 2013; A.K. Markova 1993, 1996; L.M. Mitina 2002, 2010; Yu.P. Povarenkov 2010， 2014; N.S. Pryazhnikov \& E.Yu. Pryazhnikova, 2001).

To sum up, the relevance of the research is linked to insufficient studies on motivational regulators of foreign students' educational activity in pre-university period.

\section{Discussion}

\section{Problem statement}

Motivation to learn Russian as a foreign language is a complex psychosocial process which depends on students' intrinsic motives to learn a foreign language, preparatory department professors' focus on their students' motivation and implementation of vocation-oriented and learner-oriented foreign language teaching principles, as well as integration of modern educational technologies into the educational process, which provide formation of motivation.

The experience shows that many foreign students who enter the main departments are quite unprepared for acquiring professional knowledge in Russian. Supervisors and professors who teach Russian as a foreign language relate this to insufficient attention to preparatory department foreign students' personal readiness.

Many foreign students point out at the necessity of learning Russian as a foreign language, although they do not relate the importance of Russian to the educational process. Supervisors also admit the contradictions in motivational determinants for learning a foreign language.

\section{Problem of interrelation between educational motivation and professional motivation}

Educational motivation and professional motivation are crucial for a learner-oriented linguistic education system.

Motivation is a system of stimuli which includes motives, needs, aspirations, interests, and motivational settings (Zimnyaya 1989).

One of the most popular motivation theories was developed by Abraham Maslow, who divided needs into basic ones and higher-level ones. It is higher-level needs that stimulate personal growth and development. They induce a person to self-development which means acquiring knowledge. He proved that higher-level needs appear when the lower ones are satisfied (Maslow 2014).

A high motivation to choose a profession forms a meaningful structure of educational motivation. It is dominated by intrinsic motives related to an individual's interest in the future profession (Bakhtina 1997).

Educational activity play a vital role in development of personality (V.G. Aseev, 1974; L.I. Bozhovich, 2008; A.N. Leontyev, 1971, 1983; A.K. Markova, 1990). The structure of motivation in the educational activity depends on the motives of profession choice and an individual's personal psychological qualities (Bakhtina). Educational motivation changes due to the restructuring of its motives and their integration into comprehensive frameworks (Pavlova 2005). 
T.O. Gordeeva reckons that motivation is a complex dynamic system which consists of five factors influencing the results of educational activity:

1) cognitive motivation and achievement motivation (an interest in study and conviction in its importance);

2) the ability to set achievable educational goals;

3) the ability to concentrate on the tasks and solve them;

4) belief in the ability to control the conditions of activity (self-efficacy);

5) reaction to failures during educational activity (Gordeeva 2013).

Therefore, professional motivation and professional motivation are interrelated. While professional motivation is impossible without educational motivation, educational motivation is aimed at success in professional activity.

\section{Motivation for foreign-language communication}

On coming to Russia, foreign students find themselves in a foreign-language environment. The motive to learn Russian a as foreign language is the key factor. According to I.A. Zimnyaya, "motive is the reason for the communication act, whereas communicative intention expresses the communicative objective of a speaker when thinking over the way to influence their recipient" (Zimnyaya 1991).

According to A.K. Makarova, professional motivation includes value-oriented and professional components of professionalism. As a rule, the majority of researchers try to make educational process entertaining. Nonetheless, the issues related to the determination of the role the Russian language plays in the students' future profession are still out of sight of methodology supervisors. It is generally accepted that every foreign language has a person-developing potential. Russian as a foreign language is not an exception there. Mutual influence of Russian and students' mother tongue enriches a learner's identity (Ershova 2010 p.19-23). That is why intrinsic motives to learn a foreign language should be stimulated with a specially organized educational process. A.S. Belyaev (1997) believes that intrinsic motives can be improved with motivational climate which makes educational process more entertaining and provides use of knowledge in different forms of foreign-language communication.

V.N. Perevozchikova (2005) studied the conditions of development for motivation to learn foreign language. Her research demonstrated that there are several components of educational motivation: joint educational activity; organization of informative foreign-language communication; a substantive communication plan; personal interest; realization of the activity; a developing goal-setting; emotional regulation of communicative behaviors.

Motivation for foreign-language communication is shaped at preparatory departments during a Russian as a foreign language course. The progress in learning a language is linked to communicative activity. When speaking a foreign language, a student is involved in the following communicative activities:

1) keeping communicative activity;

2) keeping communicative passivity;

3) shifting form active decisions to passive ones;

4) shifting form passive decisions to active ones. It should be noted that communicative activity is almost stable when a student switches the language from the foreign one to Russian.

The indicators of motivation foreign-language communication are:

- formation of interest in the educational process and its content;

- formation of goal-setting skills;

- formation of positive attitude to the process of learning a foreign language;

- improvement of self-confidence;

- management of intercultural communication anxiety (Perevozchikova 2005).

Motivation to learn Russian as a foreign language is determined with external and intrinsic motives. Intrinsic motives are related with the educational material and include the following components:

- communicative motivation (based on the need for communication);

- linguistic cognition (a learner's aspiration for studying linguistic phenomena); 
- county-specific studies (depend on the content and a learner's emotional interest).

\section{Observing the structure of preparatory department students' personal motivation}

\section{Diagnostic methodology}

The research "Motivation as preparatory department students' personal readiness to learn Russian as a foreign language" was based on the questionnaire developed on the basis of N.G. Luskanova's questionnaire, V.E. Milman's methodology "Diagnostics of a person's motivational structure" and T.D. Dubovitskaya's "Diagnostic methodology of educational motivation orientation".

"Diagnostic methodology of educational motivation orientation" is aimed at the identification of orientation and level of intrinsic motivation in students' educational activity. In order to identify the level of intrinsic motivation the following boundaries may be used: low level of intrinsic motivation, average level of intrinsic motivation, and high level of intrinsic motivation.

The qualitative analysis showed the following groups:

1) knowledge value;

2) self-reliance in the activity;

3) passivity;

4) hazards in studying the activity;

5) an interest in the activity;

6) negative attitude to the lessons;

7) negative attitude to the activity.

Milman's "Diagnostics of a person's motivational structure" is aimed at diagnostics of personal motivational profile (MP) and emotional profile (EP).

\section{Sample}

The survey was conducted among medical and biological preparatory department students, who expressed their attitude to learning Russian as a foreign language.

The medical and biological preparatory department students answered the questions from the questionnaire test 1-1,5 months after the course had begun. At the end of their study at preparatory departments (June-July) the re-diagnostics was conducted.

According to the survey, during the whole study at preparatory departments the interest and motivation to learn Russian as a foreign language were dynamic. While at the beginning of their study preparatory department students have high motivation to study all the aspects, with more complex educational material their motivation changes. However, it is still at a quite high level.

The survey has demonstrated that $90 \%$ of preparatory department students attend classes with pleasure, they like Russian as a foreign language course. At the same time, preparatory department students admit the complexity of the tasks. They consider Russian difficult to learn. $67 \%$ of respondents also complain about the amount and the complexity of educational goals.

Despite the hazards in learning Russian as a foreign language, the students enjoy the lessons.

Their professors also receive favorable feedback.

International diversity of the group is not an issue for the respondents. Preparatory department students point out that they have a lot of friends among their groupmates and enjoy learning Russian together.

Milman's methodology has demonstrated no leverage of day-to-day and business motives (Figure 1-2). 
The level of such business motives as general activity (57.2) and social usefulness (51.1) is lower than that of day-to-day motives (life support (59.4), comfort (69.9)). To summarize, preparatory department students do not realize the social importance of their future profession. Thus, we can conclude that the structure of preparatory department students' global motivation is not conductive to educational activity.

Figure 1. Average day-to-day orientation of foreign students in the pre-university period at the beginning and at the end of Russian language course, (\% from maximum grade)

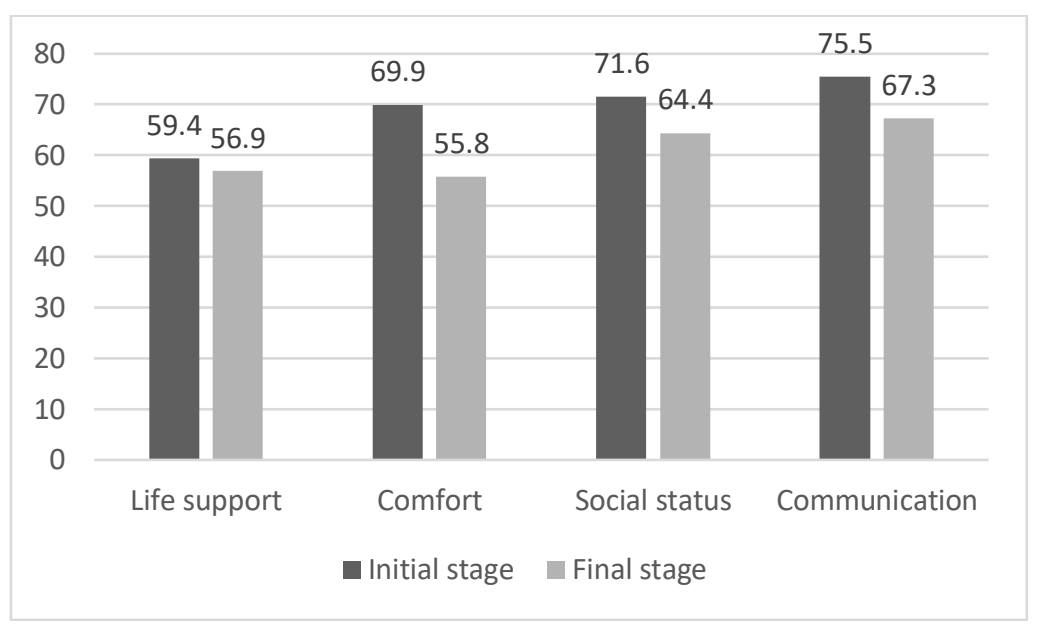

Figure 2. Average business orientation of foreign students in the pre-university period at the beginning and at the end of Russian language course, (\% from maximum grade)

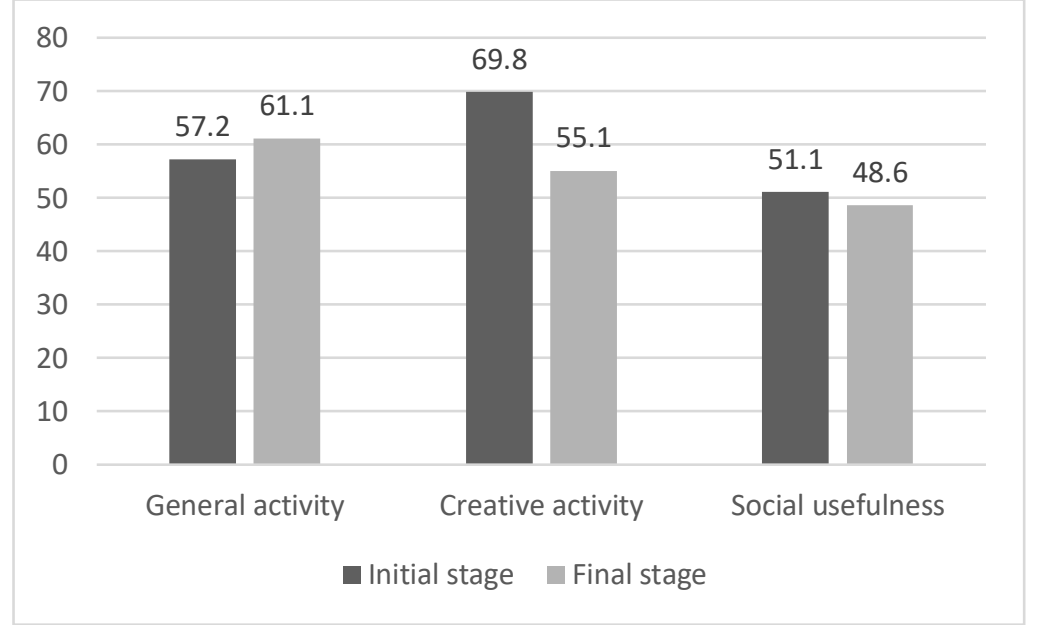

The re-diagnostics has shown a decrease in the day-to-day and business motives of preparatory department students at the final stage of learning Russian as a foreign language. The low level of creative activity (55.1) illustrates the insufficient personal self-development. The data demonstrate no connection between global motivation and educational activity. It may be related to the crisis of professional identity, general malaise from a hazardous educational process. The preparatory department students often feel disappointed in their study due to a conflict between expectations and the reality. That is why Russian as a foreign language professors are to influence students' motivation and create conditions for a stable interest in study.

The motivation researchers point out that a person learns actively only in case of dominating intrinsic motives (business motives).

Motivation for different communicative activities in Russian constantly changes from positive to negative and vice versa. Professors' teaching style also has a great impact on the 
students' motivation to learn Russian as a foreign language, as well as their didactic and educational materials. The specifics of students' future profession and motivational climate in the group influence motivation to learn Russian as a foreign language as well.

T.D. Dubovitskaya's questionnaire provides a better assessment of the influence which the educational environment has on foreign students' attitude to learning Russian as a foreign language.

The initial stage shows high levels of "independent speech" and "scientific language".

The factor analysis demonstrates that professional motivation is influenced by:

- insufficient realization of the prospects for use Russian in practice;

- difference in training level among the students in a group;

- insufficient level of speaking lingua franca;

- negative psychological attitude among weaker students.

Table 1. Average assessment of Russian in the terms of its importance for medical and biological preparatory department students at the beginning and at the end of Russian language course (the aspects of «independent speech» and «scientific language» at the beginning and at the end of Russian language course)

\begin{tabular}{|l|c|c|}
\hline \multirow{2}{*}{ Stages } & \multicolumn{2}{|c|}{ Russian as a foreign language } \\
\cline { 2 - 3 } & $\mathrm{VT}$ & $\mathrm{PM}$ \\
\hline initial stage & $9.09 \pm 1.24$ & $7.16 \pm 0.99$ \\
\hline final stage & $9.68 \pm 0.99$ & $5.89 \pm 0.77$ \\
\hline $\begin{array}{l}\text { maximum margin } \\
\text { of error }\end{array}$ & $\mathrm{p}<0.05$ & $\mathrm{p}<0.05$ \\
\hline
\end{tabular}

VT - vocational training, PM - professional motivation

Despite a decrease in motivation from initial stage to the end of the course, Russian is crucial for preparatory department students. For instance, at the beginning of the course the students give an assessment of 9.09 to VT and 7.16 to PM, whereas the final stage is assessed with 9.68 to VT and 5.89 to PM, with maximum grade of 10 and 8 correspondingly.

\section{Conclusiones}

The research leads to the following conclusions:

1) The management of motivation to learn Russian as a foreign language is the most urgent problem of teaching Russian as a foreign language.

2) Motivation is a crucial part of as preparatory department students' personal readiness to learn Russian as a foreign language

3) The analysis of educational motivation studies shows that the sources of motivation to learn Russian as a foreign language are underestimated.

4) Preparatory department students demonstrate different attitude to Russian as a foreign language. A decreased professional motivation suggests a low motivation and the need for its improvement with upgraded methods and contents which would provide higher educational motivation.

\section{References}

Aseev, V.G. (1974) Problem of motivation and personality. Theoretical problems of personal psychology. Moscow, Russia, 122-144

Bakhtina, I.A. (1997) College students' educational motivation. PhD thesis. Moscow, Russia, 144 Batkayeva, I.A., \& Mitrofanova E.A. (2012) Organization of staff salary payments. Moscow, Russia, 985 
Bazavlutskaya, L.M. (2016) Motivation and stimulation of productive activity in management. Problemy ekonomiki, upravleniya i prava sovremennoy Rossii: sbornik nauchnykh trudov po materialam I regional'noy nauchno-prakticheskoy konferentsii [The problems of economics, management and law in modern Russia: collection of scientific works on the materials of Regional Research Practice conference], 2016, 87-92

Belyayev, B.V. (1965) Essays on the psychology of teaching foreign languages. Moscow, Russia, 227

Bozhovich, L.I. Personality and its formation in childhood. St. Petersburg, Russia, 364

Dolya D.S., \& Tikhonov D.V. (2016) Optimization of staff costs and the methods of improving motivation. Nedelya nauki SPbPU: materialy nauchnoy konferentsii s mezhdunarodnym uchastiem [Science Week in SPBU: materials from International Research Conference], 185-186

Druzhilov, S.A. (2013) Conceptual model of professional activity as a psychological determinant of professionalism. Psikhologicheskie Issledovaniya, No 6(29), 4. http://psystudy.ru

Efimenko, S.V.(2011) Psychopedagogical specifics of formation of value-oriented settings among students in the conditions of foreign-language communication: Abstract from $\mathrm{PhD}$. thesis No 19.00.07. [Southern Federal University], Rostov-on-Don, Russia, 203

Ershova, N.G., \& Antonova, T.A., \& Vasilyeva, M.Yu. (2010) Integrative approach to formation of competitiveness among future physical culture specialists in teaching foreign languages. Theory and Practice of Physical Culture, No 6, 19-23

Ershova, N.G., \& Bekasova, S.N. (2012) Use of innovative educational technologies in the context of skill approach in physical culture universities. Physical Culture and Health, No 1 (37), 36-39

Gordeeva, T.O., \& Sychev, O.A., \& Osin, E.N. (2013) Students' intrinsic and external educational motivation: the sources and the impact on the psychological well-being. Voprosy Psychologii, No 1, 35-45

Khrebina, S.V., \& Khrebin, M.V. (2014) Psychological conditions for a student's personal development at university. Newsletter of North-Caucasus State Technical University, No 4 (43), 245-249

Klimov, E.A. (2003) Professional paths (Psychological view): Textbook. Moscow, Russia, 2003, 654

Leontyev, A.N. (1971) Needs, motives, emotions. Moscow, Russia, 234

Markova, A.K., \& Matis T.A, \& Orlov A.B. Formation of educational motivation: Teacher's Book. Moscow, Russia, 1990, 20-34

Maslow, A. (2014) Motivation and personality [in Russian]. St. Petersburg, Russia, 400

Mitina, L.M. (2002) Psychology of development of personal competitiveness. Voronezh, Russia, 400

Nosenko, N.P. (2006) Development of personal readiness for professional activity of professors at university. Abstract from $\mathrm{PhD}$ thesis. Krasnodar, Russia, 141

Passishnikov, A.A. (2008) Formation of personal readiness for PE professors' innovative activity at universities. Abstract from PhD thesis. Surgut, Russia, 176

Pavlova, N.A. (2005) Pedagogical university students' educational motivation. Abstract from PhD thesis. Yaroslavl, Russia, 213

Povarenkov, Yu.P., \& Slepko, Yu.N., \& Tsymbalyuk, A.E. (2014) VI Vserossiyskaya nauchnoprakticheskaya konferentsiya "Sistemogenez uchebnoy i professional'noy deyatelnosti" [VII Russian Research Practice conference 'The genesis of system in educational and professional activity']. Psychological Journal. Ed.: A.L. Zhuravlev. Vol 35, No 4, 121-123

Pryazhnikov, N.S., \& Pryazhnikova, E.Yu. (2001) Psychology of labor and dignity: textbook for university students. Moscow, Publishing House Academia, 480

Rean, A.A. (2013) Personal psychology. St. Petersburg, Russia, 288

Shadrikov V.D. (2006) The world of a person's innermost life. Moscow, Russia, 397

Solyankina, L.E. (2013) Program of psychological assistance for the students of Volgograd State Physical Education Academy in the conditions of innovative educational process. Physical education and sport training, No 1(5), 83-86 
Zimnyaya, I.A. (1989) Psychology of teaching foreign language (based on Russian as a foreign language materials). Moscow, Russia, 219

Zimnyaya, I.A. (2003) Key competences: a new paradigm of education results. Higher education today, No 5, 34-42

*This paper has been supported by the RUDN University Strategic Academic Leadership Program. 